\title{
The emerging roles of Notch signaling in leukemia and stem cells
}

\author{
Na Liu, Jingru Zhang and Chunyan Ji
}

\begin{abstract}
The Notch signaling pathway plays a critical role in maintaining the balance between cell proliferation, differentiation and apoptosis, and is a highly conserved signaling pathway that regulates normal development in a context- and dose-dependent manner. Dysregulation of Notch signaling has been suggested to be key events in a variety of hematological malignancies. Notch1 signaling appears to be the central oncogenic trigger in $\mathrm{T}$ cell acute lymphoblastic leukemia (T-ALL), in which the majority of human malignancies have acquired mutations that lead to constitutive activation of Notch1 signaling. However, emerging evidence unexpectedly demonstrates that Notch signaling can function as a potent tumor suppressor in other forms of leukemia. This minireview will summarize recent advances related to the roles of activated Notch signaling in human lymphocytic leukemia, myeloid leukemia, stem cells and stromal microenvironment, and we will discuss the perspectives of Notch signaling as a potential therapeutic target as well.
\end{abstract}

\section{Introduction}

The Notch signaling pathway is highly conserved from Drosophila to human and plays an important role in the regulation of cell proliferation, differentiation and apoptosis [1]. Moreover, it has been suggested that Notch signaling may be responsible for the development and progression of human malignancies, including leukemia.

\section{Notch signaling pathway Notch and the ligands}

Four members of Notch proteins have been identified to date in mammals, including Notch1-4 [2-5]. The Notch proteins are single-pass transmembrane receptors, which are composed of extracellular, transmembrane and intracellular domains. The extracellular domain of all Notch proteins contain epidermal growth-factor-like repeats (EGFLR) and three LIN Notch (LNR) repeats, whereas the intracellular domain consists of the RAM23 domain (RAM) and seven Ankyrin/CDC10 repeats (ANK), necessary for protein-protein interactions. Moreover, five canonical Notch ligands have been found in mammals: Dll1 (Deltalike 1), Dll3 (Delta-like 3), Dll4 (Delta-like 4), Jagged1 and Jagged2 [2-5]. Notch ligands are transmembrane

\footnotetext{
* Correspondence: jichunyan@sdu.edu.cn

Department of Hematology, Qilu Hospital, Shandong University, 107 West Wenhua Road, Jinan, Shandong 250012, P. R. China
}

proteins of which the extracellular domain contains a characteristic number of EGF-like repeats and a cysteine rich N-terminal DSL domain, responsible for the interaction with Notch receptors.

\section{Notch signaling activation}

Notch signaling has been shown to be initiated by binding of the Notch transmembrane receptors with their specific ligands between two neighboring cells [6]. Upon activation, Notch receptors undergo a cascade of metalloprotease tumor necrosis factor- $\alpha$-converting enzyme (TACE) and $\gamma$-secretase complex proteolytic cleavages, releasing the Notch intracellular domain (NICD). Subsequently, the NICD translocates into the nucleus and interacts with the DNA binding protein CSL to regulate gene expression. To date, only a few target genes have been identified. The best-known Notch target genes are two families of basic helixloop helix transcription factors: Hes (Hairy enhance of split) and Hey (Hairy/enhancer of spit related with YRPW motif) family [7]. Hes and Hey proteins are helix-loop-helix transcription factors that function as transcriptional repressors. Additionally, target genes of the Notch signaling pathways also include cyclin D1, c-myc, p21, p27, Akt, mTOR, VEGF, etc., some of which are dependent on Notch signaling in multiple tissues, while others are tissue specific [8-21] (Table 1). Nevertheless, many target genes of Notch signaling remain to be determined [8]. 
Table 1 Target genes of the Notch signaling pathways

\begin{tabular}{lll}
\hline Gene & Role & Tissues \\
\hline cyclin D1, cyclin A , p21, p27, & Cell cycle regulators & Hepatocellular cancer, renal cancer \\
\hline c-myc, NF-kB2, Akt, mTOR, & Cell proliferation and survival & Keratinocytes, liver, T-ALL, \\
\hline Hes1, Hes6 & Embryonic development & Embryonic neural progenitor cell, human pluripotent stem cells \\
\hline VEGF, VEGFR-2 & A17,18] \\
\hline MMP-9, MMP-2 & Angiopoiesis & Osteosarcoma, endothelial and neural cells. \\
\hline
\end{tabular}

\section{Notch signaling in lymphocytic leukemia $T$ cell lymphocytic leukemia}

It has been shown that Notch signaling is abnormally regulated in many human malignancies [22,23]. Notch1 mutations causing Notch signaling continuously activated have been found in nearly $60 \%$ of T cell acute lymphoblastic leukemia (T-ALL) patients, making Notch1 the most prominent oncogene specifically involved in the pathogenesis of T-ALL $[24,25]$. The characterize mutations occur mostly in the heterodimerization (HD) domain and proline, glutamic acid, serine, threonine-rich (PEST) domain of the Notch1 receptor. HD domain mutation leads to a COOH-terminally truncated NICD, whereas PEST domain mutation results in loss of the negative regulatory domain, escaping from FBXW7-mediated degradation and prolongation of the half-life of NICD [26]. Notch1 mutations have been shown to be an early, prenatal genetic event in T-ALL patients [27]. In murine models of T-ALL, Notch1 activation is responsible for directly inducing leukemia and collaborating with other initiating genetic events to perpetuate leukemic growth $[28,29]$. Moreover, our previous study has shown that Notch1 signaling is also required for hypoxia-induced proliferation, invasion and chemoresistance in T-ALL, suggesting that pharmacological inhibitors of Notch1 signaling may be attractive interventions for T-ALL treatment [30].

Additionally, other Notch signaling and target genes are also involved in the initiation and progression of T-ALL. It has been reported that Notch3 and Hes1 are highly expressed by T-ALL cells, as well as dramatically reduced or absent in remission [31]. Downregulation of Notch3 by small hair RNA (shRNA) has been found to suppress the activity of Notch signaling, leading to growth inhibition and apoptosis induction of T-ALL cells [32].

\section{B cell lymphocytic leukemia}

Interestingly, the function of Notch signaling in leukemogenesis has been shown to be either oncogenic or tumor suppressive, and it could be context dependent $[33,34]$. Notch signaling and target genes have been demonstrated to be tumor suppressive rather than oncogenic in a limited number of leukemia types, including B-ALL (Table 2). It has been reported that in contrast to T-ALL, Notch3, Jagged1, Hes2, Hes4 and Hes5 were frequently hypermethylated in B-ALL, associated with gene silencing
[33]. Furthermore, restoration of Hes5 expression by lentiviral transduction could give rise to growth arrest and apoptosis in Hes5 negative B-ALL cells but not in Hes5 expressing T-ALL cells [33]. Other investigators confirmed the fact and showed that activated forms of the 4 mammalian Notch receptors (NICD1-4) or hes1 was responsible for growth inhibition and apoptosis enhancement in both murine and human B-ALL [35-37].

In contrast with B-ALL, Notch signaling could maintain B cell chronic lymphoblastic leukemia (B-CLL) cell survival and apoptosis resistance, undoubtedly indicating an oncogenic role in B-CLL. Emerging evidence suggests that the Notch signaling network is frequently deregulated in human B-CLL with up-regulated expression of Notch1 and Notch2 as well as their ligands Jagged1 and Jagged2 [42]. Moreover, Notch signaling inhibition by the gammasecretase inhibitors (GSIs) and the specific Notch2 downregulation using small interfering RNA (siRNA) could promote B-CLL cell apoptosis $[38,42]$. It has been also reported that Notch2 is not only overexpressed in B-CLL cells but also might be related to the failure of apoptosisoriented treatment for this disease and deregulation of Notch2 signaling is involved in the aberrant expression of CD23 in B-CLL [39-41]. Taken together, these results suggest that Notch signaling is constitutively activated in B-CLL cells, and can sustain the survival of these cells.

\section{Notch signaling in myeloid leukemia}

Knowledge about the role of Notch signaling in acute myeloid leukemia (AML) is equally poorly understood. Very recently, Jagged1 and Dll1 were shown to be expressed at significantly higher levels in acute promyelocytic leukemia (APL) samples compared with all other subtypes, as well as normal myeloid populations [43]. Inhibition of Notch signaling by GSIs could reduce self-renewal and colony

Table 2 Notch in B cell Lymphocytic leukemia

\begin{tabular}{llll}
\hline Gene & Role & Leukemia types & Comments \\
\hline Notch1 & Tumor suppressor & B-ALL & {$[35]$} \\
\hline Notch2 & Oncogene & B-CLL & {$[37-39]$} \\
\hline Notch3, Notch4 & Tumor suppressor & B-ALL & {$[33,40]$} \\
\hline Hes1 & Tumor suppressor & B-ALL & {$[41]$} \\
\hline Hes5 & Tumor suppressor & B-ALL & {$[33]$} \\
\hline
\end{tabular}


formation of $\mathrm{Kit}^{+} \mathrm{Lin}^{-} \mathrm{Sca}^{+}$cells from pre-leukemic Ctsg-PML-RARA mice [43]. Our previous study has also demonstrated that Dll4 and Notch1 expression were significantly higher in untreated AML patients than in the normal controls, and provides evidence that the activation of Notch signaling may indicate an unfavorable prognosis in AML [44]. These data suggest that Notch signaling can promot AML development [45]; however, other studies have shown opposite function of Notch signaling in AML (Table 3). A significant decrease in the levels of the Notch ligand and activated receptors as well as target genes was reported to be lower in AML samples than in normal hematopoietic stem cells (HSCs), suggesting that Notch signaling is not activated in AML [46-48]. Kannan et al. have found that all four Notch homologues and Hes1 were sufficient to inhibit the growth and induced caspase-dependent apoptosis of AML, which were associated with B cell lymphoma 2 (BCL2) loss and enhanced p53/p21 expression [45]. Additionally, the dnMAML (a pan-Notch inhibitor) could not affect AML proliferation in vitro but lead to dramatic increases in leukemia burden in two xenograft mouse models, which was associated with p53 dysregulation [45]. The 17-aa peptide with Notch agonist activity was able to activate Notch signaling to induce apoptosis of AML cells $[45,49,50]$. Besides inducing apoptosis, the recombinant Notch ligand proteins, Dll1 and Dll4 could alter AML blast cells into macrophage-like cells morphologically and increase the expression of differentiation markers such as CD13 or CD14 [51]. Tohda et al. also found that the Notch ligands tended to induce differentiation under the specific conditions rather than promoted the self-renewal capacity of AML cells [52]. Overall, different researchers and experiment methods come to different conclusions, illustrating the highly context-dependent nature of the pathway. Due to the complexity of the Notch pathway and limited tools to specifically modulate the this pathway, the function of this signaling is still unclear, and additional studies are needed to clarify the role of various Notch receptors in AML.

Notch signaling appears to play a tumor suppressive role in chronic myeloid leukemia (CML). It is reported that overexpression of the active form of Notch1 or Notch2 in $\mathrm{K} 562$ cells resulted in the inhibition of proliferation, accompanied by increased Hes1 mRNA level $[54,55]$. On the other hand, attenuation of Notch signaling by overexpression of a dominant-negative RBP-J calledRBPJR218H led to the increased proliferation of K562 cells. Moreover, activation of Notch signaling was found to inhibit the colony-forming activity of K562 cells while repression of Notch signaling played the opposite role [55]. These results provide evidence that Notch signaling might play a role as a tumor suppressor in CML.

\section{Notch signaling in leukemia stem cells}

Leukemia stem cells (LSCs) arise either from corrupted HSCs or from more differentiated and committed progenitors that acquire self-renewal potential [56-58]. Therefore, targeting this unique property of LSCs-self-renewal capacity —is thought to be a promising way to eradicate disease if one can determine which pathways are critical for LSC, but not HSC. Notch signaling is active in HSCs in vivo and downregulated as HSCs differentiated. Inhibition of Notch signaling could lead to accelerated differentiation of HSCs in vitro and depletion of HSCs in vivo $[59,60]$. Furthermore, Notch1 drives cell fate decision (the choice between TCR $\gamma$ / $\delta$ or $\alpha / \beta$ and between $\mathrm{CD} 4^{+}$or $\mathrm{CD} 8^{+}$) by inductive interactions from thymic stromal cells $[61,62]$, suggesting that Notch1 expression is finely regulated during T-cell lineage development [63]. Notch1 is also reported to plays a role in rescuing $\mathrm{T}$ cells from apoptosis [64].

To date, the role of Notch signaling in LSCs has not yet been examined adequately and seems to be context dependent. Notch signaling was shown to be silenced in $\mathrm{CD} 4^{+} / \mathrm{CD}^{-} 8^{-}$stem/multipotential progenitor populations from AML patients compared to normal CD $34^{+}$stem cells. Recently, inactivating mutations of Notch signaling have been described in patients with chronic myelomonocytic leukemia (CMML) [53]. In vivo studies have also revealed both oncogenic and tumor suppressive functions for Notch signaling (Figure 1). In an MLL-AF9-induced mouse AML model, Notch signaling was inactive in $\mathrm{CD} 34^{+} / \mathrm{CD} 38^{-}$ stem/progenitor cells and upregulation of Notch signaling using genetic Notch gain of function models could result in the proliferation inhibition of this populations. Moreover, in vitro activation of Notch signaling using synthetic Notch ligand led to rapid cell cycle arrest, differentiation, and apoptosis of AML-initiating cells [65]. Notch1-3 $3^{-1-}$ or $\mathrm{Ncstn}^{-/-}$mice was also found to develop an aberrant accumulation of granulocyte/monocyte progenitors (GMP), extramedullary hematopoieisis and the induction of

Table 3 Notch in myeloid leukemia

\begin{tabular}{lllll}
\hline Leukemia types & Role & Mechanism & Comments \\
\hline Non-APL AML & Tumor suppressor & B cell lymphoma 2 (BCL2) loss and enhanced p53/p21 expression & [45] \\
\hline APL & Oncogene & $\begin{array}{l}\text { Jagged1 and DIl1 were overexpressed. GSIs could reduce self-renewal } \\
\text { and colony formation of Kit + Lin-Sca1+ cell }\end{array}$ & [43] & \\
\hline CMML & Tumor suppressor & Notch1-3-/- or Ncstn-/- mice developed CMML-like disease & & {$[53]$} \\
\hline CML & Tumor suppressor & Inhibition of proliferation & {$[54,55]$} \\
\hline
\end{tabular}




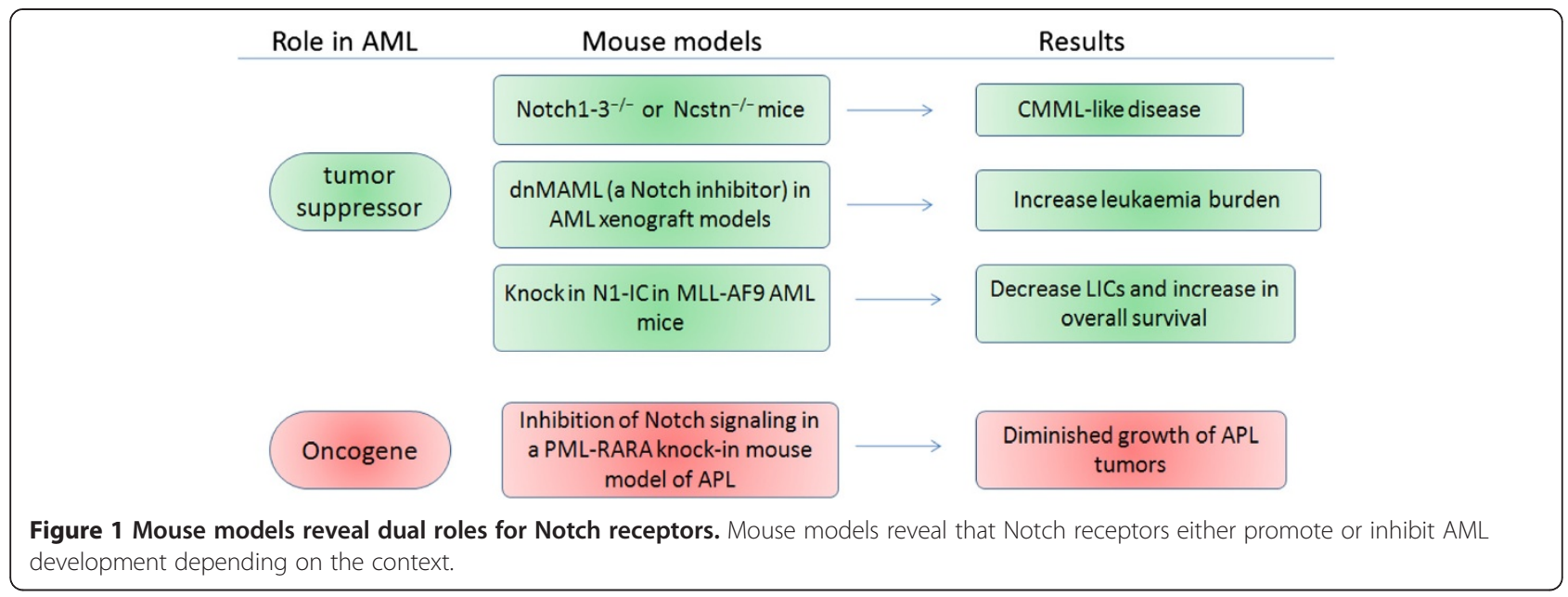

CMML-like disease. Furthermore, ectopic expression of Notch1-IC or Hes1 could suppress the expression of key GM commitment genes such as Cebpo and Pu.1, and the CMML-like disease developing in the $\mathrm{Ncstn}^{-1-}$ animals [53]. However, an oncogenic role for Notch signaling has been identified by other groups. Grieselhuber et al. reported that Jagged1 was higher in $\mathrm{Kit}^{+} \mathrm{Lin}^{-} \mathrm{Scal}^{+}$ cells from pre-leukemic Ctsg-PML-RARA mice, and both genetic and pharmacologic inhibition of Notch signaling abrogated the enhanced self-renewal seen in hematopoietic stem/progenitor cells [43]. Taken together, increasing evidence suggests that Notch signaling is involved in the regulation of self-renewal capacity of LSCs in murine models and human disease, and point out where Notch signaling be uniquely required in leukemia.

\section{Activation of Notch signaling by stromal microenvironment}

Leukemia cell survival relies on leukemic microenvironment, which is composed of bone marrow stromal cells (BMSCs), endothelial cells and other factors. Accumulating evidence emphasized the importance of Notch signaling in the cross-talk between leukemia cells and their stromal microenvironment. BMSCs were shown to induce upregulation of Notch signaling molecules, such as Notch1, Notch3 and4 or Jagged1/2 and Dll1 [40,66]. Moreover, activation of Notch signaling by stromal microenvironment were necessary for leukemia cell survival by preventing blast cell apoptosis and favoring their reciprocal interactions and cross-talk with bone marrow microenvironment [66-68]. Our previous study reported that Notch-1 activation was induced by coculture with BMSCs and down-regulation of Notch-1 increased cocultured Jurkat cell sensitivity to chemotherapy $[40,66]$. Florence et al. also found that coculture of primary human T-ALL with a mouse stromal cell line expressing the Dll1 reproducibly allowed maintenance of $\mathrm{T}-\mathrm{LiC}$ and long-term growth of blast cells through rescuing from apoptosis [69].
The molecular mechanisms of apoptosis resistance may be associated with a variety of cytokines, such as IL-7 [70,71], lymphocyte function-associated antigen-1 (LFA-1) and intercellular adhesion molecule-1 (ICAM-1) [71]. Inactivation of Notch signaling resulted in the decrease of leukemia cell survival, either cultured alone or cocultured in presence of stromal cells from normal donors and leukemia patients [40]. In addition, previous in vitro studies have demonstrated that endothelial cells enhance proliferation and survival of AML cells [72]. Our study showed a bidirectional cross-talk between endothelial and AML cells that had a promoting effect on endothelial cell function, and elucidated a novel mechanism by which the interplay between AML and endothelial cells promotes angiogenesis through VEGF activation of the Notch/Dll4 pathway [67].

\section{Inhibitors of Notch signaling and the potential clinical application}

The specific and profound involvement of Notch signaling in various leukemic types makes it an ideal target for pharmacological intervention. Several strategies have been proposed to inhibit or modulate this signaling [73,74]. The most widely used drug to globally inhibit Notch

\begin{tabular}{|c|c|c|}
\hline Test & Preclinical study & Phase I \\
\hline Drug & RO4929097 & MK-0752 \\
\hline \multirow[t]{2}{*}{ Methods } & $\begin{array}{l}8 \text { mice (leukemia models) } \\
\text { were used in each control } \\
\text { or treatment group. }\end{array}$ & \multirow{2}{*}{$\begin{array}{l}\text { Six adult and two pediatric } \\
\text { patients with leukemia } \\
\text { (seven with T-ALL and one } \\
\text { with } A M L \text { ) received MK-0752 }\end{array}$} \\
\hline & $\begin{array}{l}\text { Percentages of human } \\
\text { CD45+ cells were } \\
\text { determined }\end{array}$ & \\
\hline Results & $\begin{array}{l}\text { No significance in } \\
\text { event-free survival [53] }\end{array}$ & $\begin{array}{l}\text { Limited antitumor activity and } \\
\text { major gastrointestinal toxicity }\end{array}$ \\
\hline Comments & {$[75]$} & [76] \\
\hline
\end{tabular}


signaling is GSIs, which block the cleavage of Notch at the cell membrane, inhibiting release of the transcriptionally active Notch intracellular domain (NICD) subunit. A lot of clinical research or preclinical testing have focused on testing GSIs in the treatment of leukemia, but the results were initially disappointing (Table 4). It has been reported that RO4929097, one of GSIs, could induce insignificant differences in event free survival distribution compared to control in 0 of $8(0 \%)$ of the evaluable ALL xenografts mice [75]. A phase I clinical trial also showed that MK-0752, another GSIs, had limited antitumor activity in relapsed T-ALL patients [76]. What is more, GSIs are nonspecific and can inhibit Notch signaling in the gut, leading to gastrointestinal toxicity, which also limit its application. However, in an attempt to the clinical application of GSIs, dexamethasone was found to abrogate GSI-induced toxicity in the gut and as well GSIs treatment could reverse glucocorticoid resistance in T-ALL patients [77]. Therefore, these results supported a role for combination therapy with GSIs plus glucocorticoids in the treatment T-ALL. In another attempt to remedy this issue, inhibitory antibodies have recently been synthesized for all Notch receptors. A Notch1-specific antibody significantly induced cell cycle arrest and reduced cell proliferation in T-ALL cells. Moreover, in mouse xenograft T-ALL and colon cancer models, the Notch1-specific antibody could induce significant tumor regression and slowing of growth [74], which would pave the way for new clinical trials to evaluate the efficacy of more selective and less toxic antibody-based therapies. The overwhelming potential of Notch-based cancer treatments cannot be ignored.

\section{Conclusions}

Controversy will remain, as we do not understand the complexity of the Notch pathway and tools to specifically modulate the Notch pathway are still limited. Further studies assessing the levels of Notch activation and inhibition in leukemia still need to be carried out. Further advancement in understanding the molecular events of Notch signaling can potentially lead to further clinical benefit.

\section{Competing interests}

The authors declare no competing financial interests.

\section{Authors' contributions}

All authors have contributed to data preparation, drafting and revising the manuscripts. All authors have read and approved the final manuscript.

Received: 30 June 2013 Accepted: 15 July 2013

Published: 18 July 2013

\section{References}

1. Capaccione KM, Pine SR: The Notch signaling pathway as a mediator of tumor survival. Carcinogenesis 2013, 34(7):1420-1430

2. Del Amo FF, Smith DE, Swiatek PJ, Gendron-Maguire M, Greenspan RJ McMahon AP, Gridley T: Expression pattern of Motch, a mouse homolog of Drosophila Notch, suggests an important role in early postimplantation mouse development. Development 1992, 115(3):737-744.
3. Weinmaster G, Roberts VJ, Lemke G: Notch2: a second mammalian Notch gene. Development 1992, 116(4):931-941.

4. Lardelli M, Dahlstrand J, Lendahl U: The novel Notch homologue mouse Notch 3 lacks specific epidermal growth factor-repeats and is expressed in proliferating neuroepithelium. Mech Dev 1994, 46(2):123-136.

5. Uyttendaele H, Marazzi G, Wu G, Yan Q, Sassoon D, Kitajewski J: Notch4/int-3, a mammary proto-oncogene, is an endothelial cell-specific mammalian Notch gene. Development 1996, 122(7):2251-2259.

6. Fehon RG, Kooh PJ, Rebay I, Regan CL, Xu T, Muskavitch MA, ArtavanisTsakonas S: Molecular interactions between the protein products of the neurogenic loci Notch and Delta, two EGF-homologous genes in Drosophila. Cell 1990, 61(3):523-534.

7. Iso T, Kedes L, Hamamori Y: HES and HERP families: multiple effectors of the Notch signaling pathway. J Cell Physiol 2003, 194(3):237-255.

8. Borggrefe T, Oswald F: The Notch signaling pathway: transcriptional regulation at Notch target genes. Cellular and molecular life sciences: CMLS 2009, 66(10):1631-1646.

9. Qi R, An H, Yu Y, Zhang M, Liu S, Xu H, Guo Z, Cheng T, Cao X: Notch1 signaling inhibits growth of human hepatocellular carcinoma through induction of cell cycle arrest and apoptosis. Cancer Res 2003, 63(23):8323-8329.

10. Sjolund J, Johansson M, Manna S, Norin C, Pietras A, Beckman S, Nilsson E, Ljungberg B, Axelson H: Suppression of renal cell carcinoma growth by inhibition of Notch signaling in vitro and in vivo. J Clin Invest 2008, 118(1):217-228.

11. Oswald F, Liptay S, Adler G, Schmid RM: NF-kappaB2 is a putative target gene of activated Notch-1 via RBP-Jkappa. Mol Cell Biol 1998, 18(4):2077-2088.

12. Nickoloff BJ, Qin JZ, Chaturvedi V, Denning MF, Bonish B, Miele L: Jagged-1 mediated activation of notch signaling induces complete maturation of human keratinocytes through NF-kappaB and PPARgamma. Cell Death Differ 2002, 9(8):842-855.

13. Hales EC, Orr SM, Larson Gedman A, Taub JW, Matherly LH: Notch1 regulates AKT activation loop (T308) dephosphorylation through modulation of the PP2A phosphatase in PTEN-null T-cell acute lymphoblastic leukemia cells. J Biol Chem 2013 [Epub ahead of print]

14. Pajvani UB, Qiang L, Kangsamaksin T, Kitajewski J, Ginsberg HN, Accili D: Inhibition of Notch uncouples Akt activation from hepatic lipid accumulation by decreasing mTorc1 stability. Nat Med 2013 [Epub ahead of print].

15. Allen TD, Rodriguez EM, Jones KD, Bishop JM: Activated Notch1 induces lung adenomas in mice and cooperates with Myc in the generation of lung adenocarcinoma. Cancer Res 2011, 71(18):6010-6018.

16. Weng AP, Millholland JM, Yashiro-Ohtani Y, Arcangeli ML, Lau A, Wai C, Del Bianco C, Rodriguez CG, Sai H, Tobias J, et al: c-Myc is an important direct target of Notch1 in T-cell acute lymphoblastic leukemia/lymphoma. Genes Dev 2006, 20(15):2096-2109.

17. Lee JB, Werbowetski-Ogilvie TE, Lee JH, McIntyre BA, Schnerch A, Hong SH, Park IH, Daley GQ, Bernstein ID, Bhatia M: Notch-HES1 signaling axis controls hemato-endothelial fate decisions of human embyronic and induced pluripotent cells. Blood 2013 [Epub ahead of print].

18. Murai K, Philpott A, Jones PH: Hes6 is required for the neurogenic activity of neurogenin and NeuroD. PLoS One 2011, 6(11):e27880.

19. Li Y, Zhang J, Zhang L, Si M, Yin H, Li J: Diallyl trisulfide inhibits proliferation, invasion and angiogenesis of osteosarcoma cells by switching on suppressor microRNAs and inactivating of Notch-1 signaling. Carcinogenesis 2013, 34(7):1601-1610.

20. Thomas JL, Baker K, Han J, Calvo C, Nurmi H, Eichmann AC, Alitalo K: Interactions between VEGFR and Notch signaling pathways in endothelial and neural cells. Cellular and molecular life sciences: CMLS 2013, 70(10):1779-1792.

21. Wang Z, Banerjee S, Li Y, Rahman KM, Zhang Y, Sarkar FH: Down-regulation of notch-1 inhibits invasion by inactivation of nuclear factor-kappaB, vascular endothelial growth factor, and matrix metalloproteinase- 9 in pancreatic cancer cells. Cancer Res 2006, 66(5):2778-2784.

22. Zang S, Chen F, Dai J, Guo D, Tse W, Qu X, Ma D, Ji C: RNAi-mediated knockdown of Notch-1 leads to cell growth inhibition and enhanced chemosensitivity in human breast cancer. Oncol Rep 2010, 23(4):893-899.

23. Miyamoto S, Nakanishi M, Rosenberg DW: Suppression of colon carcinogenesis by targeting Notch signaling. Carcinogenesis 2013 [Epub ahead of print].

24. Weng AP, Ferrando AA, Lee W, Morris JP, Silverman LB, Sanchez-lrizarry C, Blacklow SC, Look AT, Aster JC: Activating mutations of NOTCH1 in human T cell acute lymphoblastic leukemia. Science 2004, 306(5694):269-271.

25. Sulis ML, Williams O, Palomero T, Tosello V, Pallikuppam S, Real PJ, Barnes K, Zuurbier L, Meijerink JP, Ferrando AA: NOTCH1 extracellular 
juxtamembrane expansion mutations in T-ALL. Blood 2008, 112(3):733-740.

26. O'Neil J, Grim J, Strack P, Rao S, Tibbitts D, Winter C, Hardwick J, Welcker M, Meijerink JP, Pieters R, et al: FBW7 mutations in leukemic cells mediate NOTCH pathway activation and resistance to gamma-secretase inhibitors. J Exp Med 2007, 204(8):1813-1824.

27. Eguchi-Ishimae M, Eguchi M, Kempski H, Greaves M: NOTCH1 mutation can be an early, prenatal genetic event in T-ALL. Blood 2008, 111(1):376-378.

28. van den Brandt J, Kwon SH, McPherson KG, Petrovic S, Zettl A, Muller-Hermelink HK, Reichardt HM: Unexpected features of acute T lymphoblastic lymphomas in Notch1IC transgenic rats. Eur J Immunol 2006, 36(8):2223-2234.

29. Lin YW, Nichols RA, Letterio JJ, Aplan PD: Notch1 mutations are important for leukemic transformation in murine models of precursor-T leukemia/ lymphoma. Blood 2006, 107(6):2540-2543.

30. Zou J, Li P, Lu F, Liu N, Dai J, Ye J, Qu X, Sun X, Ma D, Park J, et al: Notch1 is required for hypoxia-induced proliferation, invasion and chemoresistance of T-cell acute lymphoblastic leukemia cells. J Hematol Oncol 2013, 6:3.

31. Bellavia D, Campese AF, Checquolo S, Balestri A, Biondi A, Cazzaniga G, Lendahl U, Fehling HJ, Hayday AC, Frati L, et al: Combined expression of pTalpha and Notch3 in T cell leukemia identifies the requirement of preTCR for leukemogenesis. Proc Natl Acad Sci U S A 2002, 99(6):3788-3793.

32. Xiang J, Ouyang $Y$, Cui $Y$, Lin F, Ren J, Long M, Chen $X$, Wei J, Zhang H: Silencing of Notch 3 using shRNA driven by survivin promoter inhibits growth and promotes apoptosis of human T-cell acute lymphoblastic leukemia cells. Clin Lymphoma Myeloma Leuk 2012, 12(1):59-65.

33. Kuang SQ, Fang Z, Zweidler-McKay PA, Yang H, Wei Y, Gonzalez-Cervantes EA, Boumber Y, Garcia-Manero G: Epigenetic inactivation of notch-hes pathway in human B-cell acute lymphoblastic leukemia. PLoS One 2013, 8(4):e61807.

34. Gothert JR, Brake RL, Smeets M, Duhrsen U, Begley CG, Izon DJ: NOTCH1 pathway activation is an early hallmark of SCL T leukemogenesis. Blood 2007, 110(10):3753-3762

35. Zweidler-McKay PA, He Y, Xu L, Rodriguez CG, Karnell FG, Carpenter AC, Aster JC, Allman D, Pear WS: Notch signaling is a potent inducer of growth arrest and apoptosis in a wide range of B-cell malignancies. Blood 2005, 106(12):3898-3906.

36. Nwabo Kamdje AH, Mosna F, Bifari F, Lisi V, Bassi G, Malpeli G, Ricciardi M, Perbellini O, Scupoli MT, Pizzolo G, et al: Notch-3 and Notch-4 signaling rescue from apoptosis human B-ALL cells in contact with human bone marrow-derived mesenchymal stromal cells. Blood 2011, 118(2):380-389.

37. Kannan S, Fang W, Song G, Mullighan CG, Hammitt R, McMurray J, ZweidlerMcKay PA: Notch/HES1-mediated PARP1 activation: a cell type-specific mechanism for tumor suppression. Blood 2011, 117(10):2891-2900.

38. Hubmann R, Hilgarth M, Schnabl S, Ponath E, Reiter M, Demirtas D, Sieghart $W$, Valent P, Zielinski C, Jager $U$, et al: Gliotoxin is a potent NOTCH2 transactivation inhibitor and efficiently induces apoptosis in chronic lymphocytic leukaemia (CLL) cells. Br J Haematol 2013, 160(5):618-629.

39. Hubmann R, Schwarzmeier JD, Shehata M, Hilgarth M, Duechler M, Dettke $M$, Berger R: Notch2 is involved in the overexpression of CD23 in B-cell chronic lymphocytic leukemia. Blood 2002, 99(10):3742-3747.

40. Duechler M, Shehata M, Schwarzmeier JD, Hoelbl A, Hilgarth M, Hubmann $R$ : Induction of apoptosis by proteasome inhibitors in B-CLL cells is associated with downregulation of CD23 and inactivation of Notch2. Leukemia 2005, 19(2):260-267.

41. Hubmann R, Duchler M, Schnabl S, Hilgarth M, Demirtas D, Mitteregger D, Holbl A, Vanura K, Le T, Look T, et al: NOTCH2 links protein kinase C delta to the expression of CD23 in chronic lymphocytic leukaemia (CLL) cells. BrJ Haematol 2010, 148(6):868-878.

42. Rosati E, Sabatini R, Rampino G, Tabilio A, Di lanni M, Fettucciari K, Bartoli A, Coaccioli S, Screpanti I, Marconi P: Constitutively activated Notch signaling is involved in survival and apoptosis resistance of B-CLL cells. Blood 2009, 113(4):856-865.

43. Grieselhuber NR, Klco JM, Verdoni AM, Lamprecht T, Sarkaria SM, Wartman $L D$, Ley TJ: Notch signaling in acute promyelocytic leukemia. Leukemia 2013, 27(7):1548-1557.

44. Zhang J, Ma D, Ye J, Zang S, Lu F, Yang M, Qu X, Sun X, Ji C: Prognostic impact of delta-like ligand 4 and Notch1 in acute myeloid leukemia. Oncol Rep 2012, 28(4):1503-1511.

45. Kannan S, Sutphin RM, Hall MG, Golfman LS, Fang W, Nolo RM, Akers $L$, Hammitt RA, McMurray JS, Kornblau SM, et al: Notch activation inhibits AML growth and survival: a potential therapeutic approach. $J$ Exp Med 2013, 210(2):321-337.
46. Chiaramonte R, Basile A, Tassi E, Calzavara E, Cecchinato V, Rossi V, Biondi A, Comi P: A wide role for NOTCH1 signaling in acute leukemia. Cancer Lett 2005, 219(1):113-120.

47. Chen PM, Yen CC, Wang WS, Lin YJ, Chu CJ, Chiou TJ, Liu JH, Yang MH: Down-regulation of Notch-1 expression decreases PU.1-mediated myeloid differentiation signaling in acute myeloid leukemia. Int J Oncol 2008, 32(6):1335-1341.

48. Palomero T, McKenna K, ON J, Galinsky I, Stone R, Suzukawa K, Stiakaki E, Kalmanti M, Fox EA, Caligiuri MA, et al: Activating mutations in NOTCH1 in acute myeloid leukemia and lineage switch leukemias. Leukemia 2006, 20(11):1963-1966.

49. Etchin J, Sanda T, Mansour MR, Kentsis A, Montero J, Le BT, Christie AL, McCauley D, Rodig SJ, Kauffman M, et al: KPT-330 inhibitor of CRM1 (XPO1)-mediated nuclear export has selective anti-leukaemic activity in preclinical models of T-cell acute lymphoblastic leukaemia and acute myeloid leukaemia. Br J Haematol 2013, 161(1):117-127.

50. Rakowski LA, Garagiola DD, Li CM, Decker M, Caruso S, Jones M, Kuick R, Cierpicki T, Maillard I, Chiang MY: Convergence of the ZMIZ1 and NOTCH1 pathways at C-MYC in acute T lymphoblastic leukemias. Cancer Res 2013, 73(2):930-941.

51. Yatim A, Benne C, Sobhian B, Laurent-Chabalier S, Deas O, Judde JG, Lelievre JD, Levy Y, Benkirane M: NOTCH1 nuclear interactome reveals key regulators of its transcriptional activity and oncogenic function. $\mathrm{Mol}$ Cell 2012, 48(3):445-458.

52. Yamamoto K, Nakamachi Y, Yakushijin K, Miyata Y, Okamura A, Kawano S, Matsuoka H, Minami H: A novel TRB@/NOTCH1 fusion gene in T-cell lymphoblastic lymphoma with $\mathrm{t}(7 ; 9)(q 34 ; q 34)$. Eur J Haematol 2013, 90(1):68-75.

53. Klinakis A, Lobry C, Abdel-Wahab O, Oh P, Haeno H, Buonamici S, van De Walle I, Cathelin S, Trimarchi T, Araldi E, et al: A novel tumour-suppressor function for the Notch pathway in myeloid leukaemia. Nature 2011, 473(7346):230-233

54. Yang Z, Yang C, Zhang S, Li Y, Chen J: Notch2 inhibits proliferation of chronic myeloid leukemia cells. Oncology letters 2013, 5(4):1390-1394.

55. Yin DD, Fan FY, Hu XB, Hou LH, Zhang XP, Liu L, Liang YM, Han H: Notch signaling inhibits the growth of the human chronic myeloid leukemia cell line K562. Leuk Res 2009, 33(1):109-114.

56. Jenkinson S, Koo K, Mansour MR, Goulden N, Vora A, Mitchell C, Wade R, Richards S, Hancock J, Moorman AV, et al: Impact of NOTCH1/FBXW7 mutations on outcome in pediatric T-cell acute lymphoblastic leukemia patients treated on the MRC UKALL 2003 trial. Leukemia 2013, 27(1):41-47.

57. Hannon MM, Lohan F, Erbilgin Y, Sayitoglu M, O'Hagan K, Mills K, Ozbek U, Keeshan K: Elevated TRIB2 with NOTCH1 activation in paediatric/adult T-ALL. Br J Haematol 2012, 158(5):626-634

58. Ma W, Gutierrez A, Goff DJ, Geron I, Sadarangani A, Jamieson CA, Court AC, Shih AY, Jiang Q, Wu CC, et al: NOTCH1 signaling promotes human T-cell acute lymphoblastic leukemia initiating cell regeneration in supportive niches. PLoS One 2012, 7(6):e39725.

59. Buontempo F, Chiarini F, Bressanin D, Tabellini G, Melchionda F, Pession A Fini M, Neri LM, McCubrey JA, Martelli AM: Activity of the selective IkappaB kinase inhibitor BMS-345541 against T-cell acute lymphoblastic leukemia: involvement of FOXO3a. Cell Cycle 2012, 11(13):2467-2475.

60. Tzoneva G, Ferrando AA: Recent advances on NOTCH signaling in T-ALL. Curr Top Microbiol Immunol 2012, 360:163-182.

61. Hasserjian RP, Aster JC, Davi F, Weinberg DS, Sklar J: Modulated expression of notch1 during thymocyte development. Blood 1996, 88(3):970-976.

62. Washburn T, Schweighoffer E, Gridley T, Chang D, Fowlkes BJ, Cado D, Robey E: Notch activity influences the alphabeta versus gammadelta $T$ cell lineage decision. Cell 1997, 88(6):833-843.

63. Haydu JE, De Keersmaecker K, Duff MK, Paietta E, Racevskis J, Wiernik PH, Rowe JM, Ferrando A: An activating intragenic deletion in NOTCH1 in human T-ALL. Blood 2012, 119(22):5211-5214.

64. Shelly LL, Fuchs C, Miele L: Notch-1 inhibits apoptosis in murine erythroleukemia cells and is necessary for differentiation induced by hybrid polar compounds. J Cell Biochem 1999, 73(2):164-175.

65. Lobry C, Ntziachristos P, Ndiaye-Lobry D, Oh P, Cimmino L, Zhu N, Araldi E, Hu W, Freund J, Abdel-Wahab O, et al: Notch pathway activation targets AMLinitiating cell homeostasis and differentiation. J Exp Med 2013, 210(2):301-319.

66. Guo D, Ye J, Li L, Dai J, Ma D, Ji C: Down-regulation of Notch-1 increases co-cultured Jurkat cell sensitivity to chemotherapy. Leuk Lymphoma 2009, 50(2):270-278 
67. Zhang J, Ye J, Ma D, Liu N, Wu H, Yu S, Sun X, Tse W, Ji C: Cross-talk between leukemic and endothelial cells promotes angiogenesis by VEGF activation of the Notch/DII4 pathway. Carcinogenesis 2013, 34(3):667-677.

68. Nefedova Y, Cheng P, Alsina M, Dalton WS, Gabrilovich DI: Involvement of Notch-1 signaling in bone marrow stroma-mediated de novo drug resistance of myeloma and other malignant lymphoid cell lines. Blood 2004, 103(9):3503-3510.

69. Armstrong F, Brunet de la Grange P, Gerby B, Rouyez MC, Calvo J, Fontenay M, Boissel N, Dombret H, Baruchel A, Landman-Parker J, et al: NOTCH is a key regulator of human T-cell acute leukemia initiating cell activity. Blood 2009, 113(8):1730-1740.

70. Scupoli MT, Perbellini O, Krampera M, Vinante F, Cioffi F, Pizzolo G: Interleukin 7 requirement for survival of T-cell acute lymphoblastic leukemia and human thymocytes on bone marrow stroma. Haematologica 2007, 92(2):264-266.

71. Winter SS, Sweatman JJ, Lawrence MB, Rhoades TH, Hart AL, Larson RS: Enhanced T-lineage acute lymphoblastic leukaemia cell survival on bone marrow stroma requires involvement of LFA-1 and ICAM-1. Br I Haematol 2001, 115(4):862-871.

72. Hatfield K, Ryningen A, Corbascio M, Bruserud O: Microvascular endothelial cells increase proliferation and inhibit apoptosis of native human acute myelogenous leukemia blasts. International journal of cancer Journal international du cancer 2006, 119(10):2313-2321.

73. Sharma A, Rangarajan A, Dighe RR: Antibodies against the extracellular domain of human Notch1 receptor reveal the critical role of epidermal-growth-factor-like repeats $25-26$ in ligand binding and receptor activation. Biochem J 2013, 449(2):519-530.

74. Wu Y, Cain-Hom C, Choy L, Hagenbeek TJ, de Leon GP, Chen Y, Finkle D, Venook R, Wu X, Ridgway J, et al: Therapeutic antibody targeting of individual Notch receptors. Nature 2010, 464(7291):1052-1057.

75. Kolb EA, Gorlick R, Keir ST, Maris JM, Lock R, Carol H, Kurmasheva RT, Reynolds CP, Kang MH, Wu J, et al: Initial testing (stage 1) by the pediatric preclinical testing program of RO4929097, a gamma-secretase inhibitor targeting notch signaling. Pediatr Blood Cancer 2012, 58(5):815-818.

76. Deangelo DJ, Stone RM, Silverman LB, Stock W, Attar EC, Fearen I, Dallob A, Matthews C, Stone J, Freedman SJ, Aster J: A phase I clinical trial of the notch inhibitor MK-0752 in patients with T-cell acute lymphoblastic leukemia/lymphoma (T-ALL) and other leukemias. J Clin Oncol 2006, 24(18S). Abstr \#6585.

77. Real PJ, Tosello V, Palomero T, Castillo M, Hernando E, de Stanchina E, Sulis ML, Barnes K, Sawai C, Homminga I, et al: Gamma-secretase inhibitors reverse glucocorticoid resistance in T cell acute lymphoblastic leukemia. Nat Med 2009, 15(1):50-58.

doi:10.1186/2050-7771-1-23

Cite this article as: Liu et al.: The emerging roles of Notch signaling in leukemia and stem cells. Biomarker Research 2013 1:23.

\section{Submit your next manuscript to BioMed Central and take full advantage of:}

- Convenient online submission

- Thorough peer review

- No space constraints or color figure charges

- Immediate publication on acceptance

- Inclusion in PubMed, CAS, Scopus and Google Scholar

- Research which is freely available for redistribution

Submit your manuscript at www.biomedcentral.com/submit
C Biomed Central 